\title{
A causa nos contratos.
}

\author{
Lino de Morais Leme \\ Catedrático de Direito Civil, na Faculdade do \\ Direito da Universidade de São Paulo.
}

Uma pessôa está em negócios com outra, para adquirir uma propriedade, por exemplo. Antes de realizado o acôrdo de vontades, antes de "fechar" o negócio, o ven. dedor pede ao comprador uma determinada importância, e êste a fornece, ou em espécie, ou em um título. Pois bem: não se realizando o negócio, pode o vendedor cobrar a importância do título? Poderá o comprador reclamar a restituição da importância que adiantou?

Aí está o problema da causa nos contratos.

Poderá o comprador, na cobrança do vendedor, alegar falta de causa para o título? Poderá o vendedor reclamar a devolução e alegar que se trata de um pagamento indevido, porque não houve causa para o mesmo?

Esse é o problema que vamos examinar.

No direito romano, a causa dos contratos era fonte geradora do mesmo. Em uns contratos havia a solenidade, quando se tratava de stipulatio; noutros a tradição, quando se tratava de um contrato real. Havia a causa dos contratos, que era encontrada no formalismo, que caraterizava o direito romano. Mas havia, ao lado dos contratos, as obrigacões fora do contrato, ou obrigações extra-contratuais. Em relação a estas podiam ser invocadas as condictiones: causa data causa non secuta (D., 12,7).

Verificava-se o condictio sine causa, no caso de alguém haver prometido sem causa, ou pago o que não era devido; 
no caso de a promessa ter, desde a origem, carecido de causa, etc. Podia esta "conditio" ser intentada por aquilo que tivesse sido recebido sem justa causa, ou por causa que houvesse sido injusta. No direito romano a causa nos contratos era encontrada no seu formalismo e, nas obrigações fora de contrato, não subordinadas ao mesmo formalismo, nos casos em que pudesse ser invocada uma condictio. Domat, grande jurisconsulto francês, em seu trabalho "Lois civiles", extendeu, aos contratos, aquêles principios que, no direito romano, se aplicavam às obrigações extracontratuais. A causa, para êle, é o fundamento da obrigação, que, nos "contratos onerosos", se encontra, para cada parte, na obrigação assumida pela outra, e, nos a "título gratuito", no prazer de fazer o bem.

Domat foi o autor da teoria da causa, no direito moderno.

Depois, Pothier distingue entre causas geradoras das obrigações e causa dos contratos.

As causas geradoras das obrigações são: o contrato, os atos ilícitos e a vontade unilateral.

Em seguida o Código francês enumera a causa como um dos requisitos dos contratos (art. 1108).

Além do Código francês, outros enumeram a causa como requisito dos contratos (Código italiano, art. 1.325; Cód. argentino, art. 499; Cód. chileno, art. 1.145; Cód. belga, art. 1.108; Cód. uruguaio, art. 1.287; Cód. venezuelano, art. 1.141; Cód. espanhol e cubano, art. 1.261; Cód. holandês, Cód. rumeno). O Código português e o brasileiro não apontam a causa como requisito dos contratos, mas a ela fazem referência: o primeiro, nos arts. 657 a 660, e no 292; o segundo, no art. 90.

O Cód. uruguaio (art. 1.287) assim conceitúa: "Em todo contrato oneroso, es causa para obligar-se cada parte contratante, la ventaja o provecho que le procura la otra parte. Si el contrato es gratuito, la causa se encuentra en la mera liberalidade del bienhechor". E', em forma sin- 
tética, o conceito do Cód. espanhol (art. 1274). O Cód. argentino (art. 499) equipara a causa às fontes das obrigações, dizendo: "No hay obligación sin causa, es decir, que sea derivada de uno de los hechos, o de uno de los actos lícitos o ilícitos, de las relaciones de familia, o de las relaciones civiles".

Outros códigos não fazem referência nenhuma à causa: o alemão, $\cdot$ o suiço, o peruano, o mexicano. Não se deve entender, porém, dizem os escritores causalistas, de que não haja obrigação sem causa. Entre êsses causalistas estão Capitant, Traviesas, Carboni, e é o que se infere da proibição de enriquecimento ilícito. Michele Carboni diz: “A causa é um elemento necessário nos contratos e, sendo uma entidade verdadeira, embora abstrata, pode suprimir-se-lhe o nome, que ela se mantém do mesmo modo".

Regelsberger diz: "Não ha ato jurídico sem causa. $O$ ato jurídico não é um fim, em si; êle é concluído, tendo em vista um fim determinado, e é o fim que se designa sob o nome de causa". A transmissão de um bem, a criação e extinção de uma obrigação não são um fim em si, mas um meio para alcançar um fim.

Acrescentam ainda os escritores causalistas que, na jurisprudência anglo-norte americana, se aponta como um dos requisitos do contrato a consideration, que é a causa.

Essa questão de a causa ser ou não um requisito dos contratos tem dividido os escritores, apontando-se numerosos anti-causalistas, e, em numero não menor, os causalistas. Entre os anti-causalistas citam-se PLANioL, LAUrent, Huc, Windscheid; entre nós Clovis Bevilaqua, Carvalho de Mendonça (Manoel Inácio). Se formos procurar que é que os escritores causalistas consideram causa, veremos que as opinióes variam. Para Salvat, a fonte ou causa geradora das obrigações. Fitring diz que é o lado econômico do negócio. Outros dizem que é o fim do negócio; assim Chironi, Dernburg distinguem entre causa subjetiva e objetiva, o fim a realizar e o fim realizado, 
respetivamente. Para Natrini a causa objetiva é elemento de fato externo, regulado pelo direito objetivo, como a ocupação; e a causa subjetiva é o processo psicológico, a aplicação às ações humanas da lei de causalidade. Barassi vê na causa o motivo principal; AuBry, o motivo jurídico suficiente.

Essas opiniões podem ser reduzidas a duas: a que considera a causa a fonte geradora, e a que a considera como causa final. Assim podemos dizer que os escritores causalistas consideram a causa final como a causa dos contratos.

Os anti-causalistas dizem que essa noção de causa é ilógica e inutil; ilógica, porque se pode ver no contrato bilateral, por exemplo, a anterioridade nas obrigações de qualquer das partes, de maneira que a obrigação do vendedor seja a causa da obrigação do comprador, e vice-versa; e inútil, porque, dizem, a causa corresponde ao objeto, equipara-se ao objeto, ou ao consentimento.

Quando se diz que um contrato não tem causa, quer-se dizer que lhe falta objeto, ou que o consentimento procede de um vício.

Planiol diz, da causa: "É doutrina perfeitamente inutil para a teoria dos atos jurídicos"

Será então uma doutrina ilógica, ou inútil? Pode-se responder aos que apontam o primeiro vício que, quando se trata da causa, não se está inuicando a causa inicial, e, sim, a causa final, e que esta surge concomitantemente para ambas as partes, no contrato bilateral; não é inútil, pois evita o locupletamento.

Portanto, desaparece o vício da ilogicidade, contra essa teoria. Será porém uma doutrina inútil? Os causalistas dizem que o objeto do contrato responde à pergunta "Quid debetur"? "Cur debetur"? Que se deve? Porque se deve? E a pergunta a que corresponde a causa é o objeto. Se considerarmos que na repetição do indébito o fundamento é que não houve uma razão para a obrigação, que se trata de uma obrigação sem causa, vemos que o locupletamento deriva de falta de causa. 
O movimento anti-causalista começa em 1896, com Ernest, que com uma brochura - "La cause est - elle une condition essentielle pour la validité des conventions?", publicada por ocasião da revisão do código belga, pediu a supressão dos textos que se referiam à causa.

Com qual corrente está a verdade? Se com a primeira, qual o verdadeiro conceito de causa nas obrigações?

Em todas as obrigações ha os motivos impulsivos e os motivos finais. Quem adquire uma propriedade é levado por motivo impulsivo - o desejo de aplicar o dinheiro, e um motivo final - o de obter lucro com êsse emprêgo de capital. A causa, porém, não se encontra aí: êles são apenas as razões psicológicas que determinam o negócio. Ao lado, porém dessas razões psicológicas, ha o escopo jurídico - dar uma quantia por uma coisa, e é êste escopo jurídico o que recebe a tutela do direito, embora também a receba o motivo, quando expresso como razão determinante ou sob a forma de condição. Em outras palavras se podia dizer que a causa, nas obrigações, é o correspectivo ou o correlativo, mau grado a opinião contrária de Demogue; e quem se obrigou sem correspectivo se entende ter-se obrigado sem causa.

Já no D.R. havia "condictiones", destinadas a proteger quem se obrigou sem causa. Se alguém assumiu uma obrigação para realizar certo negócio, não realizado êste deixa de haver o correspectivo, e se extingue a obrigação.

Tal solução não podia deixar de ser acolhida pelo direito de todos os tempos, que procura impedir o locupletamente à custa alheia. Dispensar a causa não só nas obrigações, mas em todos os atos jurídicos, equivale a querer subverter o escopo do direito.

Mas pergunta-se: e nas doações, nos atos unilaterais que não têm correspectivo, qual será a causa? Não se confunde ela com o motivo Se é a vontade de retribuir um serviço, uma dedicação, será o motivo impulsivo; se a de 
enriquecer o patrimônio alheio, sem correspectivo, será o motivo final.

Realmente, o assunto se presta a controvérsias, mais de interesse teórico do que prático, visto que o problema surge apenas nos contratos bilaterais. Mas, se não houvesse uma causa, distinta dos motivos, podia-se confessar que ela se confunde, nesse caso, com êles, como fazem a doutrina e a jurisprudência francesa, desde Domat. Ou então se poderia restringir o conceito de causa aos negócios bilaterais.

A nosso ver, no entanto, a explicação é a seguinte: 0 direito tutela os escopos jurídicos, que podem ser o propósito de obter um correspectivo, ou o de exercer um ato de liberalidade. E aí esta: em uma doação, ha uma causa - exercer um ato de liberalidade; e ha um ato impulsivo - o afeto, a gratidão; e há um motivo final - o enriquecimento de patrimônio alheio, sem correspectivo.

Dizer que se deve distinguir, nas doações, entre as volições e os motivos próximos, é fazer obra de sutileza e de contradição, porque êsses motivos próximos não constituem a causa nos negócios jurídicos bilaterais.

Alguns códigos confundiam a causa e a condição, confusão a que nada se poderia objetar se dela não resultasse o êrro tão difundido de se considerar, como causa, escopo juridico prático, razão econômico-jurídica do negócio, a razão determinante, o motivo ou a condição principal. Em tal terreno vemos o código austríaco, quando no art. 901, dispõe - "Se as partes fizeram do motivo ou fim final de seu consentimento uma condição expressa, êste motivo ou fim final deve ser considerado como uma outra condição. Fóra êsse caso as enunciações dêsse gênero não têm nenhum efeito sôbre a validade dos contratos a título oneroso. Mas nos contratos a título gratuito, é preciso aplicar as regras editadas pelas disposições de última vontade, e o nosso Código, que estabeleceu, no art. 90: "Só vicia o ato a falsa causa expressa como razão determinante ou sob forma de condição" Não ha conpendir, pois, causa e condição. 
Uma coisa, porém, é dizer que todo o ato jurídico deve ter uma causa, e outra impôr-se, ao credor, a obrigação de provar a causa da obrigação, ou do negócio jurídico. $E$ sob êste aspecto que tem interêsse a distinçãa entre obrigações que têm e as que não têm causa.

Figuremos o caso comum de uma letra de câmbio. É uma obrigação sem causa. Não, porém, porque não deva ter uma causa, mas porque o credor é dispensado de provar a causa da obrigação. Cabe ao devedor, podendo usar de exceção pessoal contra o credor, a alegação e a prova de falta de causa para a obrigação.

o mesmo acontece ao direito civil, no qual as obrigações sem causa vieram a ser admitidas por influência do direito mercantil que, devido a condições especiais, ocupa, em regra, a vanguarda do progresso do direito. São as chamadas obrigações abstratas. Nelas cabe ao devedor, que alega, provar a falta de causa.

Se a obrigação deve ter uma causa, quer isso dizer que só excepcionalmente valham as obrigações nas quais se encontra expressa a causa? - Não. A necessidade de constar do "instrumentum" a causa da obrigação, só podia ser levantada perante aquêles códigos que enumeram expressamente a causa como um dos elementos do ato jurídico. Não perante o nosso Código Civil, que não a aponta entre os elementos essenciais. Nem por isso, no entanto, deixa a causa de ser um dos elementos da obrigação, o sopro vital das mesmas. Ela é uma daquielas verdades jurídicas universais, um daqueles principios imanentes do direito, que não precisam estar escritos nas leis, para que sejam reconhecidos. Por isso não encontraram éco as palavras de Laurent, como êste reconhece no Avant _- Projet de révision du Code civil, no qual conservou a exigência de causa para as obrigações, em virtude de a sua opinião ter ficado isolada na doutrina e na jurisprudência.

Embora não explícita, o nosso Código civil implicitamente admite a necessidade de uma causa para o negócio jurídico. 
Que é a exceção "non adimpleti contractus", consubstanciada no art. 1092, senão o reconhecimento dessa causa? A anulação da alienação aleatória, por dolo do que não ignorava o desaparecimento da alea (art. 1121), não significa que a falta de causa anula o contrato? Que faz o Código, nos artigos $865,869,879,882$, senão reconhecer a insubsistência jurídica das obrigações sem causa? Porque é nula a venda de cousa alheia?

Não confundamos "causa" com "motivo". Igualmente, não a confundamos com o objeto que, nos negócios jurídicos bilaterais, é duplo. Mas fixemos que ela é o escopo jurídico-prático, ou razão econômico-jurídica do negócio. Faltar ela ao negócio é faltar-lhe o seu sôpro vital. Expressa, ou não, ela se incorpora aos negócios jurídicos. Explícita ou implícita na lei, bem haja a jurisprudência que sempre a reconheceu. 